\title{
Factors Affecting the Implementation of Canal Blocking Development as A Fire Prevention Solution In River Village Tohor Regency
}

\author{
Febri Yuliani ${ }^{1}$ \\ Nova Erlina ${ }^{2}$
}

\begin{abstract}
The area of forest and burning land in Riau Province until 2016 has reached 3,218 hectares with the highest number of fires in Rokan Hilir Regency with 32 points. Other fire spots are also spread in Pelalawan, Meranti, Rokan Hulu, Bengkalis, Inhil, and Inhu districts. Meanwhile, forest fires and peat lands in the eastern coastal region also continue. Up to now, there have been 310.25 hectares of peat land already burned in Meranti Regency. To know and analyze the factors that influence the development of canal blocking as a peat land fire prevention solution in Sungai Tohor village, Kepulauan Meranti regency. The type of this research is qualitative with explorative method. In the construction of canal blocking as a peat land fire prevention solution in Sungai Tohor Village is influenced by several factors. The first is the government regulation factor, community participation in the form of participation and public awareness in the construction of canal blocking. As well as public awareness as a subject who felt the benefits of the existence of this blocking canal. Next is the local wisdom of peat communities. Which communities should maintain the sustainability of peat lands that are the source of their lives that have traditionally used them to cultivate sago.
\end{abstract}

\section{Keywords:}

canal blocking; land and forest fire; government regulation.

\section{Introduction}

The landscape of Southeast Asia consists of mountains, tropical forests, lowlands, peat swamps, and plantations. Indonesia is an archipelagic country rich in natural resources, especially forests. Indonesia's forest is the third largest forest in the world after Brazil and Zaire. Forest area in Indonesia is estimated to reach 120.35 million hectares or about $63 \%$ of land area. The spread of forests in Indonesia is almost all over the archipelago, including
Riau Province. Therefore, Indonesia is one of the lungs for all countries in the world, where various flora and fauna, mining products and other resources that we get from Forest.

Forest is also a natural resource that provides excellent benefits for human welfare, either tangible or intangible benefit. Real benefits or direct benefits of forest include wood, forest products follow-up and others. While the benefits of invisible or indirect benefits of forest among others water regulation, recreation,

\footnotetext{
${ }^{1}$ Prodi Ilmu Administrasi Publik, Fakultas Ilmu Sosial dan Ilmu Politik, Universitas Riau Email: febby_sasha@yahoo.co.id

2 Prodi Ilmu Administrasi Publik, Fakultas Ilmu Sosial dan Ilmu Politik, Universitas Riau Email: novaerlina@gmail.com
} 
education, comfortable environment and others (Affandi \& Patana in Latifah, 2004, p. 2).

Peat lands are one of the marginal land types selected primarily by large plantations, as they are relatively rarer and thus the likelihood of land use conflicts is relatively small. Although peat lands have a very strategic function because Indonesia is a significant producer and consumer of wood commodities, paper, and palm oil industries, the transfer of service or reclamation with the drainage of natural peat land in Indonesia is inevitable. The removal of peat land functions has occurred in the last few decades and is still ongoing until now.

These peat swamp forests are increasingly being logged and replaced by plantation companies with timber and especially oil palm. To produce oil palm, the water level in the swamplands must be lowered through drainage. Due to this waste, the organic peat soil will dry out, become sensitive to fire and fire.

To establish a plantation, drainage canals are dug to remove the water. After the water is removed, the drained organic material will be broken down and disposed of as carbon dioxide into the air. It contributes to climate change. Especially when logging activities are done on a large scale. Canals and ditches are used for public transportation and woodcuts. This will result in water flowing out of the peat dome and water will decrease. Water loss on carbon soils causes sequestration of $3-5 \mathrm{~cm}$ per year for peat soil. This makes the landscape more sensitive to flooding during the rainy season. In the dry season, the oxidation will continue, and the soil surface becomes progressively lower. This is what causes a fire in peat land will be very vulnerable.

Also, the lack of cheap, easy and quick land clearing technology encourages people to burn when preparing their land for agricultural or plantation business. The less prudent land clearing activity that the community conducts is due to the socio-economic conditions and the assumption that the ashes of burning can become fertilizer. Also, the existence of industrial timber plantation (HTI) and plantation companies that utilize the community covertly conduct land clearing with how to burn, so that the cost of land clearing can be suppressed, has also triggered the occurrence of land and garden fires.

Wet tropical forests that have not been disturbed, generally utterly resistant to fire and will only burn after a prolonged drought period. On the contrary, forests that have been logged and degraded and overgrown are much more susceptible to fires.

Peat fires are the result of the irresponsible use of peat swamps. The canals built by the company cause the peat lands to be damaged and dry and become flammable. Reflecting on the smoke haze of the previous year, the government should have a robust solution to solve the problem of land fires. However, in fact, the limitations of water is still a classic problem.

Limited availability of water at the time of firefighting led to community initiatives such as those conducted by the people of Sungai Tohor Village. The construction of the barrier on the canal can be an alternative option to anticipate peat fires. The channels in the peat lands are closed during the dry season, so the soil remains moist, and in case of fire, water sources are available. The construction of the canal in the Sungai Tohor is greatly appreciated, even during President Joko Widodo's visit.

Sungai Tohor is a village located on an island called Tebing Tinggi Timur, Meranti Islands, Riau Province which annually forest is smoldering and its smoke covers village and city to the neighboring country. This town is endowed with a dense peat swamp forest with a high level of biodiversity. Among the natural trees that grow on this island, there is a sago tree (sago). This tree gives excellent blessings sustains the economy of its citizens. 
In the Sungai Tohor, the sago tree thrives in forests where the land is wet. The growth of this type of tree depends on wet soil and peat. These trees make Sungai Tohor's citizens have a stable livelihood. However, the excessive drainage of a canal built by the company and by the government in 2007 which is now deeper underground and resulting in a drought on peat land stretches. The drainage process of peat forest overlap that occurred in the extreme that caused the vulnerability of forest fires.

Peat land fires are more dangerous than fires on dry land (mineral soil). Fire fires in peat lands have characteristics other than can produce canopy and surface flames, can also cause peat fire underground that produces thick smoke so much harm to various parties. In addition to the vegetation fire on the surface, the layer of peat is also burned and lasts longer, resulting in thick smoke due to incomplete combustion.

The impacts of smoke on the environment can vary from local ones, i.e., blocking the landscape to allow for global warming. The adverse effects caused by land fires include various sectors of life, ranging from the disruption of people's daily lives, transportation obstacles, ecological damage, declining tourism visits, political impacts, the economy to health problems.

The Sungai Tohor peat forest fire in early 2014 was successfully extinguished after an artificial rainfall made on the orders of President Susilo Bambang Yudhoyono and managed to bring down heavy rain for three days in the context of firefighting operations. However, in mid-January 2015, the fire burned the forest again at some point in the sago company concession on Tebingtinggi Island, not far from Sungai Tohor. The company's admission is a stretch of land owned by PT LUM has damaged. In the sago company, large canals are also built, which means peat drainage is also ongoing and peat damage is increasingly making the stretch vulnerable to burning.
Through Presidential Regulation No. 1 of 2016, the Central Government established a Peat Restoration Agency. This Presidential Regulation regulating the management of peat lands with peat land restoration is one of them by building a canal block (Canal Blocking). Canal blocking is a national agenda for peat restoration with the primary objective of addressing land fires due to the destruction of peat ecosystems. Preventing peat land fires by keeping peat soil wet is considered a wiser move than time-consuming handling.

By taking advantage of the President's first momentum to have attention to the handling of smoke haze caused by forest and land fires by looking at areas where people have a desire to escape from the problems of damaged peat and fire. That is why in select Village Sungai Tohor, District Tebing Tinggi East. The President is given alternatives or options to peat repair activities, one of which is the most easily understood by the public and the most simple seen by the President is the canal blocking.

If we see earlier, the construction of canal blocking has been done since 2000 already exist in Kalimantan and some other areas in Indonesia. The canal was previously built based on local community initiatives and NGO initiatives. However, in reality, the canal blocking constructed on the Sungai Tohor has succeeded in attracting the attention of the government and even the President, so it is considered excellent and successful in responding to the solution of the smoke haze caused by forest and land fires. Evidenced by the reduced shooting that occurred in the Sungai Tohor Village even managed to reach Zero Hotspot in 2016.

\section{Literature Review}

Peat land restoration projects need to be clear about their aims. In peat bogs where carbon sequestration is a principal aim of restoration works, achieving a surface cover rich in should be the ultimate and quantifiable objective. Methods for restoration rich surface 
layers require further development and evaluation in order to produce best practice guidance. On severely damaged/modified peat lands, funding needs to be available for phased restoration. Some form of monitoring should be made a requirement of funding. Managed burning and restoration required on the impacts of grazing and trampling on active peat land. Peat land systems restoration is an effective measure to avoid further loss of peat and carbon. The evidence also suggests that peat land restoration is an effective means of enhancing carbon sequestration on less degraded sites. Peat land restoration as a potential carbon offsetting measure should be explored. A national peat land restoration strategy is needed to provide a context for the many local/regional projects planned or underway and to stimulate further bids and funding structures (Lunt, 2010).

Government targets need to be agreed for the restoration of areas of active peat. Assessments could be a carried out as part of a modification of common standard monitoring. Funding should be sought for regional research coordinators to carry out a RIAU wide co-ordinated and integrated meta-data analysis with the aim of producing best practice guidance on monitoring and peat land restoration methods. Organic rich peat soils are a major store of carbon worldwide, containing between $15-30 \%$ of the world's total soil carbon Limpens, J. et al. Peat lands and the carbon cycle: from local processes to global implications-a synthesis. (Biogeosciences, 2008, p.1475-1491)

The depletion of the peat lands will have a profound social, economic and health impact on the Indonesian population. For example, forest fires occurring in peat lands not only cause economic losses but also cause hundreds of thousands of residents to experience respiratory health problems that require careful handling. The loss of peat lands or the various damages experienced will also lead to diminished their important functions as water suppliers, flood controllers and the prevention of sea water intrusion into the mainland. If no precautionary measures are taken as well as the handling of the damage and loss of peat land, then the dangers and losses incurred will not only hit the Indonesian population alone, but will also cause environmental and social implications that are regional and even global. If the carbon in the peat is released then it will significantly increase the carbon content in the atmosphere. Not only have direct impacts on humans, peat land degradation will also have direct impacts on biodiversity life in it, including important species, such as Orangutans, about 300 species of fish and more than 2,500 plant species (about 20\% of which are known as medicinal plants). Many of these species are known to be highly dependent on and only found in peat lands. Conditions in the field show that many Indonesian people are very dependent on the value and function contained by peat lands. Peat swamp forest products serve as the main source of community life, whether in the form of wood or non-timber, such as fruits, rattan, medicinal plants, and fish. Some of the shallow peat soil or adjacent to the mineral land is then used as an agricultural area. Unfortunately, uncontrolled development activities often have a very bad impact on peat lands, and ultimately impact on the livelihoods of local people whose lives depend on the existence of peat lands. Large scale peat land clearance will leave poverty only for the people, not only because of the loss or depletion of their livelihoods, but also because local communities must substitute or even provide additional efforts and funds to replace the reduced or even disappearing function or benefits of peat lands due to the destruction activities. (Wetlands InternationalIndonesia Programme; 2007).

\section{Methods}

The type of this research is qualitative with explorative method. Qualitative research 
with explorative method. The location of this research is in Sungai Tohor Village, Tebing Tinggi Timur Subdistrict, Meranti Islands District, Riau. The reason for choosing the location is because Sungaitohor Village became the center of study of peat restoration in Riau Province. Sungai Tohor is also made the first International Tropical Peat Restoration Laboratory in the world. Informant research is the people who observed and provide data and information, and know and understand the problem under investigation. Primary data of research obtained by interview and form. Focus Group Discussion (FGD) in research areas, Observation on perceptions and behaviors, and interviews using questionnaires. The secondary data of this study are research reports, journals, annual reports, evaluation reports, regulatory and legislative documents, minutes of meetings and other relevant documents.

\section{Results}

The development aims to raise the level of life and human welfare. Development not only produces benefits but also carries risks. No matter how good the benefits, the risks must be calculated equally. So that must be considered is how to build so that the quality of the environment and quality of life can be improved.

According to Siagian (2004) Development is a series of efforts to realize the growth and change in a planned and conscious way pursued by a State or nation to modernity in the series of nation-building. To undertake development means to prepare all the needs of the community indicated by the potential of the community. Some assets that must be owned by the community as a result of community development and development include an asset that is assumed related to the physical development effort, environmental capital, technology capital, human capital and social capital. According to Rogers in Suryono (2001) Development is a process of social change with broad participation in a society intended for social and material progress (including increased equity, freedom and other qualities that are valued) for the majority of the people through greater control which they get to their environment. The construction of physical facilities is defined as a tool or facility that can be perceived directly by the community as intended in the form of:

a. Communication infrastructure namely: roads, bridges and others.

b. Marketing infrastructure is: building, market.

c. Social infrastructure is: school buildings, houses of worship, and health centers.

d. Water supply infrastructure.

The area of tropical peat lands (swamps and forests) is estimated at 42 million hectares spread across Indonesia, Malaysia, the Amazon and Central Africa lowlands (Osaki \& Tsuji, 2016). This area stores about $148 \mathrm{Gt}$ of carbon. This area is still relatively untouched by development, and the forest is still relatively virgin. The region of Southeast Asia has about 24.78 million ha or $56 \%$ of the world's peat land. Indonesia has 14.91 million ha of peat lands, or $35.5 \%$ of the world's peat land (Osaki et al., 2016) spread over Sumatra at 6.44 million ha $(43 \%)$, Kalimantan 4.78 million ha (32\%), and in Papua 3.69 million ha (25\%). While Riau has $4,221,000$ ha of peat land (Wardhana, 2016) or $28.31 \%$ of the total peat area of Indonesia or about $65.54 \%$ of the peat area in Sumatera. The extent of 59 KHG of Riau Province reached 5,004,727.47 ha (Final Report of RPPEG, 2016), consisting of protected function 2,216,621.84 ha $(44.29 \%)$ and cultivation function 2,788,105.63 ha $(55,71 \%)$.

In 2007, Riau's peat lands were only $1,603,008$ hectares of 2,280,198 ha in 2002 (Okto Yugo Setiyo in Wardhana, 2016). This means that in 5 years, Riau has lost peat land area of 677,190 ha or about $19 \%$ with an average loss of 135,438 hectares per year. Of the 
remaining area, the National Peat Restoration Agency (BRG) has set 938,619 ha as Riau Peat restoration 2016-2020 (Wardhana, 2016). What kind of roadmap and action plan detail Riau peat restoration no information or data that can be accessed. While at the central level, the Indonesian Peat Restoration Agency (BRG, without years) has targeted 2 million hectares of peat lands to be targeted for restoration over the next five years (2016-2020) with targeted achievements of $30 \%$ (2016), 20\% (2017), 20\% (2018), and $10 \%$ (2020).

In the national peat restoration program's roadmap, Riau is one of 7 priority provinces of restoration programs other than Jambi, South Sumatra, West Kalimantan, Central Kalimantan, South Kalimantan and Papua. If the ambition of BRG RI becomes a reality, then this effort is the largest peat restoration program in the world (http://www.pengetahuanhijau. com) To support the action plan, the support of academic research on Riau's comprehensive peat ecosystem is a necessity for the successful implementation of the restoration action plan Riau peat, from the stage: the formulation of policy, implementation process, and evaluation of program impact measurable.

The success of degraded peat land restoration should be based on scientific knowledge, relevant to socioeconomic conditions, and local community engagement (Yuliani, 2017). This analysis is intended to provide an overview of the extent to which academic research on Riau's peat ecosystems has been carried out in almost three decades (1989-2017). The descriptive contents analysis used in this literature study focuses on obtaining a description of 1) research institutes, 2) research sites, and 3) variables or research parameters. The results of this analysis can be given a little contribution to the reinforcement of academic research Riau peat land ecosystem to support the success of Riau peat land restoration program. The following data on Area of Hydrological Unity in Riau Province as follows:
Table 1.

Unique Hydrology Units in The Province of Riau

\begin{tabular}{|c|c|c|c|}
\hline No & Existence & Large (HA) & $\%$ \\
\hline 1 & In the forest area & $3,287,676$ & 64.48 \\
\hline \multirow[t]{2}{*}{2} & Outside the forest area & $1,810,857$ & 35.52 \\
\hline & Total & $5,098,533$ & 100.00 \\
\hline 1 & $\begin{array}{l}\text { Nature Reserve / Nature } \\
\text { Conservation / New Park } \\
\text { Area }\end{array}$ & 231,690 & 7.05 \\
\hline 2 & Protected Forest & 31,117 & 0.95 \\
\hline 3 & Limited Production Forest & 535,233 & 16.28 \\
\hline 4 & $\begin{array}{l}\text { Permanent Production } \\
\text { Forest }\end{array}$ & $1,773,811$ & 53.95 \\
\hline \multirow[t]{2}{*}{5} & $\begin{array}{l}\text { Convertible Production } \\
\text { Forests }\end{array}$ & 715,824 & 21.77 \\
\hline & Total & $3,287,676$ & 100.00 \\
\hline
\end{tabular}

Wide unity of peat hydrology: $+5,098,533 \mathrm{Ha}$ $(56.42 \%)$ of Riau land area, spread over 59 groups in 11 districts of the city

Source: Research Results

Actions that have been undertaken include: establishment of institutional peat land managers at the site level, by (a) Optimizing the role and institutional function of the Peat Restoration Team (b) Establishment of UPT Peat (c) Optimizing UPT Unity of Forest Management (KPH)

All the action is done with the wetting movement (rewetting), done through: Development of artesian drilling well, Construction of channel canal, Supervision of water management (at company), Establishment and Training of KHG Water Management Team. Revegetation Movement, done through Making of peat land village seedlings, Making crops of peat land villages, Making horticultural seeds, Preparing crops from horticultural crops. Social Revitalization Movement of Community Economy, Development of fishery business, Development of cattle breeding business, goat, Honey bee development, Peat land ecotourism development, Development of well, Cultivation of Plant Life, Utilization and processing of sago pulp, Mangrove Crab cultivation, Sustainable Food, Establishment of Peat Concern Village. 
Based on this it is clear that the development process of change towards the better is only manifested by involving, moving the human beings both in planning, implementation, utilization and evaluate the results. In addition development is a process, it is intended that every development effort must require continuity of implementation, in the sense without knowing the deadline even in the planning can be arranged based on the principle of priority scale and a certain stage.

According to Widyati (2011) explains that the implementation of development should no longer be a government monopoly, it should also be the responsibility and the needs of society, thus the community will feel more owned and obliged to encourage the implementation of the development process in its area.

Revealed that in the development process there are two groups or sub-systems of development actors consisting of:

1. Small groups of citizens who formulate the planning and are obliged to organize and mobilize other people's to participate in development. The definition of formulating the development plan does not mean that the ideas or aspirations desired by all citizens through an agreed mechanism are channeled through group meetings or deliberations at the bottom, formal or informal institutions.

2. Broad people who participate in the development process, either in the form of inputs (ideas, costs, personnel, etc.), implementation of activities, monitoring and utilization of development results. In reality, the main implementer of development activities actually consists of this group, while the elite community only serves as a translator of policy and development planning as well as organize and mobilize community participation (Yuliani, 2017).
Construction of blocking canal has a purpose and function. In order for the purpose and function can be achieved well in accordance with the predetermined target then the blocking canal must be managed properly in accordance with the principles of management. According to Luther Gullick, there are several aspects that must be considered for the management to run smoothly and achieve satisfactory results that consist from Planning, Organizing, Staffing, Directing, Coordinating, Reporting, Budgeting (POSDCORB).

The purpose of the construction of canal blocking is to restore the wet and humid peat conditions and re-arrange the already drained peat lands. The canal blocking constructed serves to withstand the rapid flow of water from the peat dome down, directing the flow of water to the side. With the presence of the bulkhead, the water will find a way sideways, not only one direction that gives the effect of wet peat and reduces the occurrence of draining in the dome where the water source.

Also, the porous nature of the peat is like a sponge. Which if there is no water then the peat will deflate, otherwise if there is water then it expands again. So with the canal blocking will maintain the state of peat so as not to deflate. Moreover, the most important thing is when we talk about the current issue of the issue of fire prevention and haze. Construction of blocking canal is an effort to prevent the emergence or return of peat land fires and smoke haze tragedy. Also, with the construction of canal blocking then this serves to place the source of water in case of fire, to extinguish the fire. Then, in the coastal areas, the peat-peat directly opposite the beach as in Sungai Tohor, canal blocking serves to hold the rate of saltwater intrusion, helping to reduce the entry of salt water to the mainland of peat so that sago plants can grow well.

The construction of canal blocking is technically the design development planning done by the Ministry of Public Works (Public 
Works and Housing), Cipta Karya, Spatial and Water Resources (Ciptada) and technical personnel or people who have expertise in civil engineering and water science consultants who are coordinated in stages to see the status of the area whether forest or plantation. Starting from the lowest level conducted by the Forestry and Plantation Service and KPH (Forest Holders Area) Tebing Tinggi. In the Provincial Coordination with BLH (Environmental Agency) and Ciptada, as well as at the National level coordination with BRG (Peat Restoration Agency) and Ministry of Environment and Forestry. In the planning process discussed tentative activities, implementation mechanism, strategy, completeness of building and reporting. In this planning, two technical implementers of canal blocking development are Walhi (Wahana Lingkungan Hidup Indonesia) and PSB (Center for Disaster Studies) from the University of Riau in a context responsible for BRG. PSB regarding academic support in the form of researchers, Walhi in the context of how this activity is understood and conducted by the community so that the community does the involvement of this activity. BRR as the project and United Nations Development Programs (UNDP) for financial mechanism.

While in the planning village starts with deliberation to know the form of canal blocking that will be built is what, how high, what kind of equipment and materials used and what workers. This planning is done by several groups of people who are used to work there and usually make a canal channel.

The goal to be achieved from the construction of canal blocking is to re-wet the dry peat lands due to the excavation of the canal to prevent the occurrence of fires in the field of peat land. In the construction of the canal in need of careful planning which of course some things need to be considered as a procedure of consideration before the development is done so that this goal can be achieved efficiently.
The procedure to consider is the first, taking into account the topography where the canal is built. By giving priority to areas with high topography and some areas that deep peat so that water is not drained away, flowing down and be dry so easy to burn. So the program done before doing the development is survey into the field first, determine where the place will be built the right channel divider.

The second is to consider the aspect of the impact to the community associated with community activities. In this case, the cultivated communities that are parallel to the wet peat wants, more to the impact of commodities that have turned them on like sago. For that purpose, communication and discussion with the community are then determined and agreed upon the construction of the channel canal ideally done by the local community with the assistance of supervision or supervision and assistance from experts such as from universities, from government institutions or NGOs. For the development of the canal can be realized by the goals and needs of the community. It takes more importance, how the community becomes more owned, and build public awareness.

As mentioned earlier, this study aims to determine the factors that influence the development of canal blocking as a peat land fire prevention solution in Sungai Tohor village, Kepulauan Meranti regency. From the results of research conducted on the construction of canal blocking as a peat land fire prevention solution in Sungai Tohor Village, Meranti Regency Regency and also supported by interviews from some informants considered to understand the problem, the researcher will explain the factors that influence the development of canal blocking as a solution prevention of peat land fires in Sungai Tohor Village, Kepulauan Meranti regency.

The factors that influence the construction of canal blocking as a peat land fire prevention solution in Sungai Tohor Village, Kepulauan Meranti Regency are as follows: 


\section{Government Regulation}

The regulation through BRG policy is a strategic step as a factor influencing the development of canal blocking as a peat land fire prevention solution in Sungai Tohor Village, Kepulauan Meranti District.

\section{Community Participation}

Factors influencing the construction of canal blocking as a peat land fire prevention solution in Sungai Tohor village, Meranti regency is one of them is community participation. Community participation is an important factor in determining whether or not an activity is successful. What is meant by community participation here is community participation and awareness in development canal blocking.

In addition, the form of community participation can also be the community's own awareness in understanding the community's need for the existence of canal blocking in Sungai Tohor Village. This is supported through interviews with Deputy IV of the Peat Restoration Agency in research and development as follows: the successful development of canal blocking cannot be separated from the participation of Sungai Tohor Village community. Community participation in the construction of blocking canal is good enough. Because the community itself is the subject of benefiting from the canal blocking. Therefore, all community members should participate in the maintenance and supervision of canal blocking in the village.

\section{Local Community Wisdom on Peat}

Local wisdom is all forms of knowledge, belief, understanding or insight and customs or ethics that guide human behavior in life within the ecological community. Local clarification is the value or behavior of local people living in interacting with the environment where he lives wisely.

Sungai Tohor is one of the largest Sago producing villages in Sumatera with different sago plantation different from sago tree in Eastern Indonesia. Most Sungai Tohor community work is sago farmers. Cultivating, producing sago and processing sago become their main staple food such as lumping sago , sago sago, sago eggs, beverage rhymes admiral, ongol-ongol and other. This has been done for generations. Sago be a source of livelihood and pride of the community Sungai Tohor Village, East Tebing Tinggi Subdistrict, Meranti Islands District, Riau Province

Sago derived from the sago tree or commonly called the tree of rumbia is the staple food of the Sungai Tohor community. This is a form that the people of Sungai Tohor village have a wisdom mindset based on local wisdom to preserve the peat swamp forest. In addition to sago cultivation, the community has also attempted to prevent the occurrence of widespread forest fires by making canals provided by insulation in order to avoid soil erosion that makes the canal not function properly.

Sungai Tohor community is very enthusiastic with sago farming that is already hereditary and is the local wisdom of local community. Society suspect, that the fire in Sungai Tohor due to the canalization by the company causing drought on peat. In addition to dry flammable peat, this also affects the growth of sago which is the source livelihoods and the economy of the people. With the canal blocking will keep the peat in wet conditions so it is not easily burned and wet peat is very compatible with sago plants whose character is like living in wetlands.

The Peat Restoration Agency is a nonstructural institution under and responsible to the President. The goal is to realize the accelerated recovery of the area and the return of hydrological functions of peat due to forest and land fires. Activities are conducted in a special, systematic, directed, integrated and comprehensive. And coordinate and facilitate peat restoration in Riau Province, Jambi, 
South Sumatera, West Kalimantan, Central Kalimantan, South Kalimantan, and Papua. The Peat Restoration Agency shall prepare a plan and implementation of a five year peat ecosystem restoration of approximately 2,000,000 (two million hectares).

Since the restoration program has been rolled out, there are still many parties who do not understand what peat land restoration is. It caused inequality in the implementation of the restoration program. So far, the community thinks that restoring peat lands is limited to government tasks, and for local governments the restoration program is only a pilot project of the central government. In fact, it is wrong, therefore the conceptualization of this restoration must be clear and submitted continuously to the government apparatus, stakeholders and the community.

This peat land restoration activity certainly involves many parties to be fully realized, together with the Peat Restoration Team (TRGD) for hair restoration program in Riau Province, there are activity plans which are: This peat land restoration activity certainly involves many parties to be fully realized, together with the Peat Restoration Team (TRGD) for hair restoration program in Riau Province, there are activity plans which are: Rewetting Program, Revegetation Program, Social Economic Revitalization Program.

The Strategic Plan of the Peat Restoration Agency 2016-2020 which contains the implementation of the restoration of damaged peat ecosystem becomes the responsibility of the government through BRG. It is contained in Presidential Regulation No. 1 of 2016 on Peat Restoration Agency. In organizing efforts to restore the functioning of the peat ecosystem to prevent recurrence of forest and land fires and the impact of smoke, BRG has the task of facilitating and coordinating the restoration of the 2 million-hectare peat ecosystem.

Based on BRG's internal and external strategic issues, BRG's strategic environment can be mapped according to existing strengths, weaknesses, opportunities and threats. From the results of the analysis, it was concluded that BRG's strategic objectives include covering protected areas and cultivation areas in hydrological unity of peat so as to be managed sustainably to support the improvement of people's welfare and the quality of human life and the environment. The Peat Restoration Agency is tasked with achieving three restoration objectives: (1) hydrological recovery, vegetation and socio-economic support of degraded peat ecosystems; (2) protection of peat ecosystems for life support; (3) rearrangement of sustainable management and utilization of peat ecosystem. From this task, the object managed by BRG is the Peat Hydrological Unity (KHG).

The management of peat ecosystems aims to achieve multi- benefits, namely economic, social, and ecological benefits. Referring to that objective, the formulation of the programs under BRG's responsibility is the Program for Facilitation and Coordination of Peat Restoration in 7 Provinces. The objective of the program is to accelerate the recovery of peat ecosystems in 7 provinces to provide sustainable use for economic, social and ecological interests. Efforts to achieve program objectives, as well as achievement of program performance indicators will be implemented through five activities. Each activity describes the execution of the duties and functions of each deputy in the BRG scope. Activities within the scope of the BRG Program, consisting of: administrative support, operational and financial management support; Planning and Cooperation; Construction, Operation and Maintenance; Education, Socialization, Participation and Partnership; as well as Research and Development.

Riau Province as one of the biggest disasters of forest and land fires province in Indonesia. The largest peak of forest and land fires in Riau Province occurred in 2014 which 
Picture 1.

Area Forest and Land Fires (Ha)

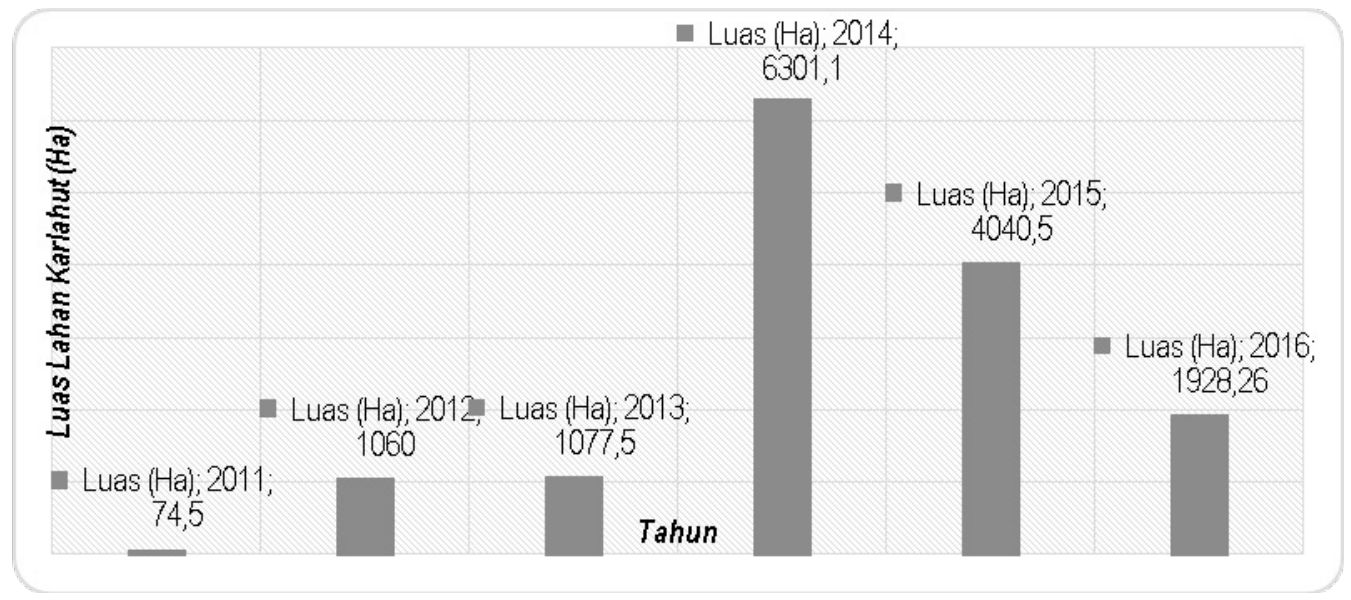

Source: Sipongi-fire land and forest monitoring, 2016

reached 6,301.10 Ha (Sipongi- forest and land fires Monitoring System, 2016). The point and area of forest and land fires area in Riau Province spread in some regencies / cities. Among them are Siak and Pelalawan districts. Despite the decrease in the area of burned land in 2016 (to an extent of 1,928.26 ha), this indicates that Karutut is still an environmental problem that has not been resolved thoroughly to date.

The data show that the priority of restoration of peat is $125,212 \mathrm{Ha}$, Priority restoration of the peat dome is $75,720 \mathrm{Ha}$, the priority of unreached peat dome limestone (protected zone) is $126,794 \mathrm{Ha}$, and the priority of post-fire 2015 restoration is 3,867 Ha.

\section{Conclusion}

Based on the results of the explanation of the results and discussion about the development of Canal Blocking as a Solution of Peat land Fire Prevention in Sungai Tohor Village it can be concluded that in the construction of canal blocking as a peat land fire prevention solution in Sungai Tohor Village is influenced by several factors. The first is the government regulation factor, community participation in the form of participation and public awareness in the construction of canal blocking. As well as public awareness as a subject who felt the benefits of the existence of this blocking canal. Next is the local wisdom of peat communities. Which community should maintain the sustainability of peat lands which are the source of their life which has been using it for generations to process sago.

From the research that has been done, the researcher gives some suggestion which hopefully can become constructive input in canal blocking construction as fire prevention solution of land, among others 1) The government and the academics and NGOs involved in the construction of canal blocking in the prevention of peat land fires determine the standard form of good canal blocking and suitable for the canal blocking that is built to be measurable. 2) To facilitate the construction, it is necessary to know the shape of the peat in an area how, its good insulation how and determine the position or location of the canal that will be built. Therefore, the government also needs to coordinate with research agencies and NGOs to create contour and hydrological maps to support the construction of canal blocking. This is so that the funds spent for the construction of canal blocking is more effective. 3) The village government should allocate funds for the maintenance of the channel canals that 
have been built so that the existing bulkhead is maintained and can last a long time. So the benefits of this canal can be long and sustainable. 4) It is expected that the management of canal blocking can be improved. 5) The community is expected to further increase its participation in supervising the construction of blocking canal and maintenance of canal blocking that has been completed in order to maintain its sustainability and also the sustainability of its benefits.

\section{References}

Badan Restorasi Gambut. (n.d.). Restorasi gambut untuk masa pepan Indonesia. Jakarta: Badan Restorasi Gambut.

Latifah, S. (2004). Penilainan ekonomi hasil hutan non kayu. Retrieved May 15, 2016, from http://library.usu.ac.id/downlo ad/fp/ hutan-siti7.pdf

Limpens, J., Berendse, F., Blodau, C., Canadell, J. G., Freeman, C., Holden, J., Roulet, N., . . -Strub, G. S. (2008). Peat lands and the carbon cycle: from local processes to global implications - a synthesis. Biogeosciences, 5(6), 1475-1491. doi: 10.5194/bg-5-1739-2008

Peatland Restoration [Review of IUCN UK Peatland programme's commision of inquiry on peatlands by Lunt, P., et al.]. (2010, December). London: Scientific Review.

Siagian, S. (2004). Teori pengembangan organisasi. Jakarta: Bumi Aksara.
Suryono, A. (2001). Teori dan isu pembangunan. Jakarta: UM-Press.

Wardhana, B. (2016). Rencana strategis badan restorasi gambut 2016-2020. Jakarta: Badan Restorasi Gambut.

Noor, Y. R., \& Heyde, J. (2007). Pengelolaan lahan gambut berbasis masyarakat di Indonesia. Bogor: Weatlands International - Indonesia Programme.

Widyati, E. (2011). Kajian optimalisasi pengelolaan lahan gambut dan isu perubahan iklim. Tekno Hutan Tanaman, $4(2), 57-68$.

Yuliani, F. (2018). Community participation on peat restoration policy for forest rescue and land in Sungai Tohor Village Meranti Island Riau Province Sumatera. Journal of Studies in Social Sciences, 17(1), 13-24.

Yuliani, F. (2017). Implementasi kebijakan restorasi gambut untuk penanggulangan kebakaran hutan dan lahan di Provinsi Riau. Pekanbaru

http://www.pengetahuanhijau.com/berita/ membangun-kolaborasi-untukpemulihan-lahan-gambut-terdegradasidi-jambi

\section{Regulations}

Presidential Regulation No. 1 of 2016 on the Agency for the Restoration of Peat lands. Government Regulation No. 71 Year 2014 on the Protection and Management of the Peat Ecosystem. 